\title{
IMPROVING THE PHYSICAL QUALITY OF STUDENTS BY PRESCRIPTION TEACHING MODE
}

\author{
MELHORA DA QUALIDADE FISICA DOS ALUNOS PELO MÉTODO DE ENSINO POR \\ PRESCRIÇÃO
MEJORA DE LA CALIDAD FÍSICA DE LOS ALUMNOS POR EL MÉTODO DE ENSEÑANZA POR PRESCRIPCIÓN

\author{
Huichang Gao' 110 \\ (Physical Education Professional) \\ 1. Xingyang College, Henan, China.

\section{Correspondence:} \\ Huichang Gao, Xingyang \\ College, Henan, 464000, China. \\ gao202101@163.com
}

\begin{abstract}
Introduction: The physique of college students is very important. The physique of college students is the prerequisite for the country's revitalization, and health is the prerequisite for the transformation of intellectual capital. Object: Aiming at the current college students' physical education class arrangements and curriculum reform, the paper uses exercise prescriptions to make a brief plan for students' physical exercise. Method: The thesis uses the exercise prescription teaching method to carry out health intervention education for middle school students, which is used to analyze the physical requirements of students. Results: After five months of fitness exercise prescription, the students' physical fitness has increased significantly. We use fitness exercise prescriptions to make students feel good about exercise. Conclusion: The application of physical and healthy exercise prescriptions can effectively improve the systematic and scientific nature of students' participation in sports and help students learn and master healthy physical and mental self-exercise skills. Level of evidence II; Therapeutic studies - investigation of treatment results.
\end{abstract}

Keywords: Physical Fitness; Students Physical Education and Training; Curriculum.

\section{RESUMO}

Introdução: O físico dos estudantes universitários é muito importante. O físico dos universitários é o pré-requisito para a revitalização do país, e a saúde é o pré-requisito para a transformação do capital intelectual. Objeto: Visando os arranjos das aulas de educação física dos atuais estudantes universitários e a reforma curricular, o artigo usa prescrições de exercícios para fazer um breve plano para os exercícios físicos dos alunos. Método: A tese utiliza o método de ensino da prescrição de exercícios para realizar educação de intervenção em saúde para alunos do ensino médio, que é utilizada para analisar as exigências físicas dos alunos. Resultados: Após cinco meses de prescrição de exercícios físicos, a aptidão física dos alunos aumentou significativamente. Usamos prescrições de exercícios físicos para fazer os alunos se sentirem bem com os exercícios. Conclusão: $A$ aplicação de prescrições de exercícios físicos e saudáveis pode efetivamente melhorar a natureza sistemática e científica da participação dos alunos em esportes e ajudá-los a aprender e dominar habilidades saudáveis de auto-exercício físico e mental. Nível de evidência Il; Estudos terapêuticos - investigação dos resultados do tratamento.

Descritores: Aptidão Física; Estudantes Educação Física e Treinamento; Currículo.

\section{RESUMEN}

Introducción: El físico de los estudiantes universitarios es muy importante. El físico de los estudiantes universitarios es el requisito previo para la revitalización del país, y la salud es el requisito previo para la transformación del capital intelectual. Objeto: Con el objetivo de los arreglos de las clases de educación física de los estudiantes universitarios actuales y la reforma del plan de estudios, el documento utiliza prescripciones de ejercicios para hacer un plan breve para el ejercicio físico de los estudiantes. Método: La tesis utiliza el método didáctico de prescripción de ejercicios para realizar la educación de intervención en salud para estudiantes de secundaria, que se utiliza para analizar los requisitos físicos de los estudiantes. Resultados: Después de cinco meses de prescripción de ejercicios físicos, la aptitud física de los estudiantes ha aumentado significativamente. Usamos recetas de ejercicios físicos para que los estudiantes se sientan bien con el ejercicio. Conclusión: La aplicación de prescripciones de ejercicio físico y saludable puede mejorar de manera efectiva la naturaleza sistemática y científica de la participación de los estudiantes en los deportes y ayudar a los estudiantes a aprender y dominar habilidades saludables de autoejercicio físico y mental. Nivel de evidencia Il; Estudios terapéuticos: investigación de los resultados del tratamiento.

Descriptores: Aptitud Física; Estudiantes Educación y Entrenamiento Físico; Curriculum. 


\section{INTRODUCTION}

Student physique is the essential condition for China to realize national rejuvenation and national prosperity. Its healthy physical and mental state is the prerequisite for its intelligent capital transformation. Since 1979, China has carried out five comprehensive and large-scale investigations on student physique and accumulated a wealth of research data. However, compared with similar foreign studies, there are more systematic investigations and fewer comprehensive practical interventions. ${ }^{1}$ This research is based on the classic concept of the physique in China, combined with the current research platform of sports and health curriculum reform, and conducted a systematic study of student physique intervention using the educational form of exercise prescription.

\section{METHOD}

\section{General information}

This study will be conducted from February 28, 2020, to July 30, 2020. The paper adopts the stratified cluster sampling method and selects 1453 middle school students in the second and second grades of 3 middle schools as the research objects. ${ }^{2}$ The average age is (15.73 \pm 3.42 ) years old.

We choose gymnastics (including aerobics), martial arts, ball games (basketball and volleyball, combined with various small ball electives) as the main curriculum resources combined with quality exercises and various sports games. We design type I fitness (physical fitness) series of exercise prescriptions and type II fitness (sports skills and health education) series of exercise prescriptions. Exercise prescriptions give full play to the autonomy and enthusiasm of physical education teachers and students. ${ }^{3}$

\section{Investigation method}

1. The measurement tools. The number of valid questionnaires measured three times before, after and after the intervention was 1250 groups. The effective rates were $85.46 \%, 86.37 \%, 86.26 \%$, and the average effective rates were $86.03 \%$. The data used for quantitative analysis in this study meets the requirements of surveying statistics. ${ }^{4}$

2. Interviews and surveys of the target population. Conduct discussions and interviews with the three primary target groups of students, teachers, and parents before, during and during the intervention education. Simultaneously, use various forms such as telephone, email, and letters to keep in touch with the key target groups to understand the intervention process and its effects.

3. Expert interviews. Before the intervention education, I visited some colleges and universities to study student physique and health experts and some senior teachers of physical education in middle schools to discuss the status quo, methods, trends and trends of sports and health education reforms, exercise prescription design and the experimental control of middle school students' physical and mental health consultation and advice on other issues.

\section{Statistical methods}

We use Spss11.0 statistical software to analyze the data using statistical description, F-test pairwise comparison, One-way ANOVA, and correlation analysis. Nonlinear problems are generally formulated as:

$$
\left(P_{1}\right) \min _{x} F(x)=\sum_{i=1}^{m}\left|f_{i}(x)\right|
$$

Among them $f_{1}(x), f_{2}(x), \cdots, f_{m}(x)\left(x \in R^{n}, m \geq 2\right)$ is a continuously differentiable function, and at least one of them is nonlinear. The nonlinear $l_{1}$ problem belongs to non-differentiable optimization, so the optimization method based on the gradient is no longer suitable for solving the nonlinear $l_{1}$ problem. ${ }^{5}$ This technique is widely used in inequalities, complementary problems, non-smooth programming problems, etc. For the nonlinear $l_{1}$ problem $P_{1}$, because

$$
F(x)=\sum_{i=1}^{m}\left|f_{i}(x)\right|=\sum_{i=1}^{m} \max \left\{f_{i}(x),-f_{i}(x)\right\}
$$

The smooth approximation function is constructed based on the above function form, and the above function is further transformed. In essence, the formula is expressed as follows:

$\max \left\{f_{i}(x),-f_{i}(x)\right\}=\max \left\{f_{i}(x), 0\right\}+\max \left\{0, \quad f_{i}(x)\right\}$

We order $g_{i}(x)=f_{i}(x), g_{i+m}(x)=-f_{i}(x), i=1,2, \cdots, m$. Therefore, the nonlinear $l_{1}$ problem model $P_{1}$ is equivalent to the following optimization problem:

$$
\left(P_{2}\right) \min _{x} \sum_{i=1}^{2 m} \max \left\{g_{i}(x), 0\right\}
$$

Since the optimization model $P_{2}$ is still a non-differentiable optimization problem, there are specific difficulties in solving it. For this purpose, it is constructed in two steps. The smooth approximation function is constructed according to the above two steps. Let

$$
\theta(t)=\frac{t+\sqrt{t^{2}+4}}{2}
$$

$$
\theta_{r}(t)=r \theta\left(\frac{t}{r}\right)=\frac{t+\sqrt{t^{2}+4 r^{2}}}{2}
$$

The function $\theta_{r}(t)=\frac{t+\sqrt{t^{2}+4 r^{2}}}{2}$ constructed by the above method satisfies property 1 , property 2 and property 3 .

\section{RESULTS}

\section{Evaluation of the effect of physical education and health exer- cise prescription on students' physical fitness intervention \\ The influence of sports and health exercise prescriptions on stu- dents' physical fitness \\ It can be seen from Table 1 that after the intervention, the rate of} excellent physical fitness of the experimental group students increased from $10.03 \%$ before the experiment to $18.73 \%$, the excellent rate increased from $26.99 \%$ to $45.13 \%$, and the failure rate decreased from $16.96 \%$ to $8.11 \%{ }^{6}$

The exercise feeling test after the intervention showed (Table 2) that comparing the two dimensions of refreshment and active participation in the experimental group was significantly higher than that in the control group $(P<0.05)$. Students'active exercise feeling indicates the mental state of students participating in physical education and health education. It is also one of the essential reasons for the formation of exercise habits.

The influence of sports and health exercise prescriptions on students' health knowledge, beliefs and behaviors

The students in the experimental group have the most significant increase in their knowledge scores after intervention. Compared with the pre-test scores, the awareness rate of knowledge after the intervention 
Table 1. Comparison of the physical fitness classification of middle school students after the intervention and during the back test.

\begin{tabular}{|c|c|c|c|c|c|}
\hline \multirow[b]{2}{*}{ Content } & \multirow[b]{2}{*}{ grade } & \multicolumn{2}{|c|}{ After the intervention } & \multicolumn{2}{|c|}{ Backrest } \\
\hline & & T-test group & $\begin{array}{l}\text { Control } \\
\text { group }\end{array}$ & Test group & $\begin{array}{c}\text { Control } \\
\text { group }\end{array}$ \\
\hline \multirow{4}{*}{$50 \mathrm{~m}$} & A & 59 & 41 & 52 & 37 \\
\hline & $B$ & 326 & 162 & 315 & 154 \\
\hline & C & 232 & 305 & 246 & 314 \\
\hline & D & 58 & 64 & 65 & 67 \\
\hline \multirow{4}{*}{$1000 / 800 \mathrm{~m}$} & A & 56 & 28 & 49 & 26 \\
\hline & $B$ & 360 & 135 & 356 & 135 \\
\hline & C & 190 & 310 & 200 & 311 \\
\hline & $D$ & 72 & 100 & 74 & 101 \\
\hline \multirow{4}{*}{$\begin{array}{l}\text { Standing } \\
\text { long jump }\end{array}$} & A & 147 & 95 & 140 & 91 \\
\hline & $B$ & 308 & 192 & 303 & 184 \\
\hline & $C$ & 177 & 241 & 186 & 254 \\
\hline & $D$ & 4 & 43 & 48 & 44 \\
\hline \multirow{4}{*}{$\begin{array}{l}\text { Pull-ups / } \\
\text { sit-ups }\end{array}$} & $A$ & 247 & 93 & 241 & 85 \\
\hline & $B$ & 232 & 156 & 221 & 154 \\
\hline & C & 156 & 214 & 171 & 224 \\
\hline & D & 44 & 108 & 44 & 108 \\
\hline \multirow{4}{*}{ Total/Average } & $A$ & 127 & 64 & 120 & 59 \\
\hline & $B$ & 306 & 161 & 299 & 156 \\
\hline & $C$ & 189 & 267 & 202 & 276 \\
\hline & $D$ & 55 & 79 & 57 & 81 \\
\hline
\end{tabular}

Table 2. Comparison of changes in feelings of middle school students' physical exercise after intervention and during back testing.

\begin{tabular}{c|c|c|c|c}
\hline \multirow{2}{*}{ Dimension } & \multicolumn{2}{|c|}{ After the intervention } & \multicolumn{2}{c}{ Backrest } \\
\cline { 2 - 5 } & Test group & Control group & Test group & Control group \\
\hline Refreshing & $8.36 \pm 2.80$ & $5.34 \pm 2.67$ & $7.81 \pm 3.09$ & $5.32 \pm 2.64$ \\
\hline Sense of quiet & $5.40 \pm 2.47$ & $5.47 \pm 2.47$ & $4.71 \pm 2.32$ & $4.60 \pm 2.57$ \\
\hline Fatigue & $5.75 \pm 2.84$ & $5.14 \pm 2.94$ & $5.35 \pm 3.02$ & $4.91 \pm 2.75$ \\
\hline Active participation & $7.88 \pm 3.53$ & $6.60 \pm 2.71$ & $7.72 \pm 3.50$ & $5.94 \pm 2.59$ \\
\hline
\end{tabular}

increased from $37.15 \%$ before the intervention to $84.19 \%$; the awareness rate of beliefs increased from $57.98 \%$ before the intervention to $92.03 \%$; the participation rate of healthy behaviors increased from $35.97 \%$ before the intervention Increase to $88.17 \%$.

\section{The impact of sports and health exercise prescriptions on students' social adaptability and mental health}

1. Social adaptability. The student's social adaptability in the experimental group increased significantly compared with their pre-test results compared with the students in the control group during the same period $(P<0.05)$.

2. Mental health. It can be seen from Figure 1 that after the intervention, the mental health of the students in the experimental group has been significantly improved $(P<0.05)$, especially the intervention effect of junior high school students $(P<0.01)$. The number of students in the experimental group with moderate or above mental problems dropped from $6.93 \%$ to $6.19 \%$. The number of students with moderate or above psychological problems in the post-test showed an upward trend $(7.19 \% \rightarrow 8.22 \%)$.

In this study, students in the experimental group who received intervention education had significant differences in the other eight dimensions after the intervention, except for the two dimensions of anxiety and learning pressure compared with the control group. Sorted according to the growth rate of non-problem students after intervention in each dimension, from largest to smallest, they are maladjustment, mood swings, psychological imbalance, anxiety, hostility, compulsion, interpersonal tension and sensitivity, depression, paranoia, and learning

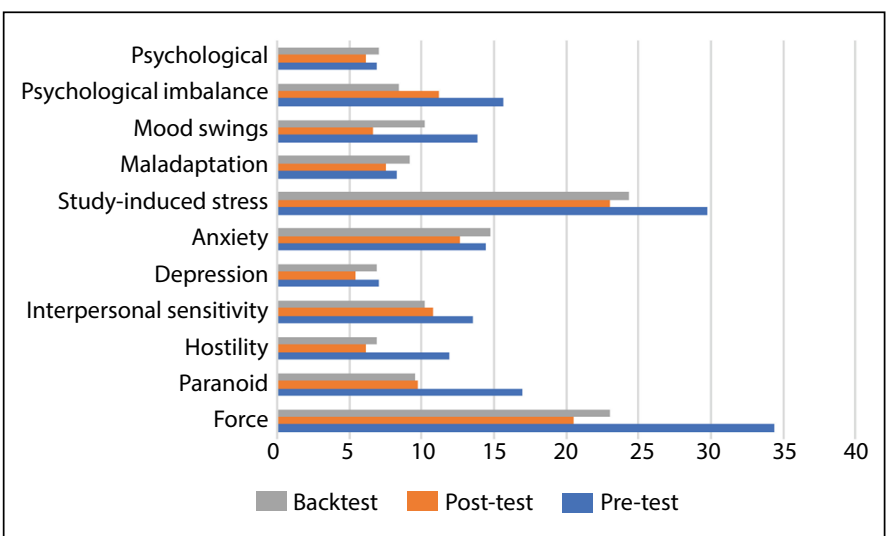

Figure 1. Comparison of changes in students with moderate or above problems in the MMHI-60 experimental group before and after the intervention.

pressure. In the intervention education, it was found that the vast majority of students hope to learn practical mental health knowledge and relieve their psychological pressure through physical activities. They also believe that physical education and youth sports clubs can relieve psychological tension in schools and increase communication opportunities with classmates. The most appropriate place (89.44\%).

\section{Evaluation of the education intervention process of sports and healthy exercise prescription}

This study conducted an educational intervention for the experimental group for five months. During and after the intervention, the researchers, teachers and students in the experimental group evaluated the selection of teaching content, teaching methods, teachers'teaching ability and effects in the experiment. The results show that $83.26 \%$ of students think this course is acceptable, $89.32 \%$ of students like or like it very much, through study, a total of $94.74 \%$ of students think they have gained, of which $52.19 \%, 23.71 \%$ and respectively $18.84 \%$ of students said they had "a lot," "more" and "some" gains.

Evaluation of expert teachers on the intervention education process

During the intervention process, three senior teachers (education inspectors) from the experimental school were hired to quantify the experimental teachers' teaching situation. Judging from the comprehensive score after the experiment, the total average score of experimental teachers is 88.85, and the score shows a trend of increasing from front to back. It shows that teachers' teaching ability is gradually improving, and they can be well qualified for intervention teaching work.

\section{Students' evaluation of intervention in the education process}

After the experiment, the experimental group students will fill in the "Comprehensive Evaluation Form of Physical Education and Health Education" to score the teaching ability and teaching situation of the experimental teachers. Mainly include teaching objectives, teaching content, teaching process and methods, basic teaching literacy, teaching immediate effect five items. The total score for each of the secondary indicators is 10 points for a total of 100 points. The average score of experimental teachers is 87.42 points.

\section{The relationship between teaching effect, teaching content, tea- ching method and teacher's teaching ability}

In the "Sports and Health Education Evaluation Form," students are asked to self-evaluate their physical education and mental health achievements on a 100-point scale. The results showed that the eight experimental classes'scores in 4 aspects were not significantly different ( $P>0.05)$. It shows that the experiment teachers' level is relatively equal, and the teacher factor has little effect on the experiment results. 


\section{DISCUSSION}

According to the "Sports and Health Curriculum Standards," this research adopts the experimental research method, uses the exercise prescription teaching method to conduct a comprehensive intervention study on middle school students' physical fitness, and conducts a comprehensive exploratory evaluation of the educational effect. Conclusion as below:

1. After five months of fitness exercise prescription exercise, the students' physical fitness has increased significantly. ${ }^{8}$ The experimental group students' excellent rate has increased by $8.70 \%$, and the failure rate has decreased by $8.85 \%$; the comprehensive scores of students' sports knowledge, beliefs, and behaviors have been greatly improved. The awareness rate has increased by $37.05 \%, 24.05 \%$, and $32.2 \%$, respectively; the use of fitness exercise prescriptions can make students feel good about exercise.

2. After the intervention education, the number of students in the experimental group with no mental health problems increased by $12.72 \%$ compared with that before the intervention, students with moderate or above problems decreased by $0.74 \%$, and the social adaptability increased by $8.65 \%$ compared with the previous test; compared with the control group Compared with that, the improvement is significant. Combined with the results of qualitative research, it shows that physical education and health education effectively improve students' mental health.

3. Middle school students have choices about the content of fitness exercise prescriptions. Organizers must carefully select exercise content and scientifically combine the physical and psychological characteristics and hobbies of middle school students of different ages and genders.

\section{CONCLUSION}

In physical exercises inside and outside of class, the application of physical and healthy exercise prescriptions cannot only effectively improve the scientific and systematic participation of students in sports but also have better exercise effects, which is conducive to students learning and mastering healthy physical and mental self-exercise skills, and improve Physical level.

The author declare no potential conflict of interest related to this article

AUTHORS' CONTRIBUTIONS: The author made significant contributions to this manuscript. Huichang Gao: writing and performing surgeries; data analysis and performing surgeries; article review and intellectual concept of the article.

\section{REFERENCES}

1. Zhang, X., Wang, X., Le, S., Ojanen, X., Tan, X., Wiklund, P., \& Cheng, S. Effects of exercise and dietary interventions on serum metabolites in men with insomnia symptoms: A 6-month randomized controlled trial. Sports Medicine and Health Science. 2020;2(2): 95-101.

2. Bajis, D., Chaar, B., Basheti, I. A., \& Moles, R. Pharmacy students' medication history taking competency: Simulation and feedback learning intervention. Currents in Pharmacy Teaching and Learning. 2019;11(10): 1002-1015.

3. Ozemek, C., Kaminsky, L. A., Brubaker, P. H., Lavie, C. J., \& Arena, R. Time to elevate the education of clinical exercise physiologists: a professional doctorate model. Translational Journal of the American College of Sports Medicine. 2019;4(18): 185-191.

4. Charette, M., Bérubé, M. Ė., Brooks, K., O'Neil, J., Brosseau, L., \& McLean, L. How well do published randomized controlled trials on pelvic floor muscle training interventions for urinary incontinence describe the details of the intervention? A review. Neurourology and urodynamics. 2020;39(1):35-44
5. Ezati, M., Keshavarz, M., Barandouzi, Z. A., \& Montazeri, A. The effect of regular aerobic exercise on sleep quality and fatigue among female student dormitory residents. BMC Sports Science, Medicine and Rehabilitation. 2020;12(1): 1-8.

6. Langelier, D. M., D'Silva, A., Shank, J., Grant, C., Bridel, W., \& Culos-Reed, S. N. Exercise interventions and their effect on masculinity, body image, and personal identity in prostate cancer-a systematic qualitative review. Psycho-oncology. 2019;28(6): 1184-1196.

7. Fibbins, H., Lederman, O., Morell, R., Furzer, B., Wright, K., \& Stanton, R. Incorporating exercise professionals in mental health settings: An Australian perspective. Journal of Clinical Exercise Physiology. 2019;8(1): 21-25.

8. Gür, F., \& Can Gür, G. Is exercise a useful intervention in the treatment of alcohol use disorder? Systematic review and meta-analysis. American Journal of Health Promotion. 2020;34(5): 520-537. 